University of Nebraska - Lincoln

DigitalCommons@University of Nebraska - Lincoln

Faculty Publications from the Harold W. Manter Laboratory of Parasitology

4-1994

\title{
Two New Species and Temporal Changes in the Prevalence of Eimerians in a Free-Living Population of Townsend's Ground Squirrels (Spermophilus townsendii) in Idaho
}

\author{
P. G. Wilber \\ University of New Mexico \\ Ben Hanelt \\ University of New Mexico \\ B. Van Horne \\ Colorado State University \\ Donald W. Duszynski \\ University of New Mexico, eimeria@unm.edu
}

Follow this and additional works at: https://digitalcommons.unl.edu/parasitologyfacpubs

Part of the Parasitology Commons

Wilber, P. G.; Hanelt, Ben; Van Horne, B.; and Duszynski, Donald W., "Two New Species and Temporal Changes in the Prevalence of Eimerians in a Free-Living Population of Townsend's Ground Squirrels (Spermophilus townsendii) in Idaho" (1994). Faculty Publications from the Harold W. Manter Laboratory of Parasitology. 176.

https://digitalcommons.unl.edu/parasitologyfacpubs/176

This Article is brought to you for free and open access by the Parasitology, Harold W. Manter Laboratory of at DigitalCommons@University of Nebraska - Lincoln. It has been accepted for inclusion in Faculty Publications from the Harold W. Manter Laboratory of Parasitology by an authorized administrator of DigitalCommons@University of Nebraska - Lincoln. 


\title{
TWO NEW SPECIES AND TEMPORAL CHANGES IN THE PREVALENCE OF EIMERIANS IN A FREE-LIVING POPULATION OF TOWNSEND'S GROUND SQUIRRELS (SPERMOPHILUS TOWNSENDII) IN IDAHO
}

\author{
P. G. Wilber, B. Hanelt, B. Van Horne*, and D. W. Duszynski \\ Department of Biology, The University of New Mexico, Albuquerque, New Mexico 87131
}

\begin{abstract}
More than 1,180 fecal samples were collected from 253 juvenile and 384 adult Townsend's ground squirrels (Spermophilus townsendii) at the Snake River Birds of Prey Area near Boise, Idaho, from February to June 1992. Oocysts of 7 eimerians were observed. Five are new host records (Eimeria beecheyi, Eimeria bilamellata, Eimeria callospermophili, Eimeria lateralis, and Eimeria morainensis), 2 species are described here as new, and new structural information on E. morainensis is added. Sporulated oocysts of Eimeria adaensis n. sp. are ovoidal, $19.6 \times 22.7(16-22 \times 18-26) \mu \mathrm{m}$ with sporocysts ellipsoidal $7.2 \times 11.9(6-10 \times 9-15) \mu \mathrm{m}$. No micropyle or oocyst residuum, but polar bodies, Stieda bodies, and sporocyst residua are present. Sporulated oocysts of Eimeria pseudospermophili $\mathrm{n}$. sp. are ovoidal, $24.7 \times 28.5(21-27 \times 25-32) \mu \mathrm{m}$ with sporocysts ellipsoidal $8.8 \times 14.2(8-10 \times 12-17) \mu \mathrm{m}$. Micropyle and oocyst residuum are absent, but polar bodies and Stieda bodies are present. Sporulated oocysts of $E$. morainensis are more variable in size and shape than originally described and contain 2 distinctly different residua not previously described. Temporal changes in the prevalence of eimerians of all 7 species combined in adult squirrels showed significant decline $\left(r^{2}=0.79, P<0.001\right)$. We hypothesize that this decline was due to drought during the period of squirrel activity. No significant temporal change in the prevalence of eimerians in juvenile squirrels was observed. The prevalence of E. callospermophili, $E$. adaensis, and all eimerians combined in adults was significantly greater than in juveniles. There was no significant difference in eimerian prevalence between male and female squirrels $(P<0.05)$.
\end{abstract}

Many surveys have identified parasites in a variety of free-living vertebrate hosts by necropsy (Ball and Lewis, 1984; Boggs et al., 1990, 1991; Gregory et al., 1992; Hudson et al., 1992; Stanton et al., 1992). Such studies can assess the parasite community at a single point in time, but they do not address temporal changes in infection patterns. In addition, removal of enough hosts to characterize the parasite community accurately may alter the relationship between the host and the parasite. Thus, results of subsequent samples of the same host population may include changes influenced by removal of hosts as well as changes characteristic of an undisturbed system.

Because there is a conspicuous lack of any largescale field studies that have examined temporal patterns of parasites in populations of unperturbed free-living hosts (Minchella and Scott, 1991), we began such a study using eimerians of Townsend's ground squirrel (Spermophilus townsendii). These are small short-eared squirrels that are important as food for cliff-nesting raptors at the Snake River Birds of Prey Area (SRBOPA) near Boise, Idaho. Townsend's ground

Received 8 June 1993; revised 29 November 1993; accepted December 1993.

* Department of Biology, Colorado State University, Ft. Collins, Colorado 80523. squirrel is an obligate hibernator and is active from February to June in most years. Helminths of these squirrels have been reported only twice (Leiby, 1962; Jenkins and Grundmann, 1973). Townsend's ground squirrels never have been examined for coccidia.

Here we describe and discuss temporal patterns of eimerian prevalence during the active season of the squirrels in 1992 (February-June), describe 2 new species of Eimeria, and give new structural information on the oocysts of Eimeria morainensis Torbett, Marquardt, and Carey, 1982.

\section{MATERIALS AND METHODS}

Our study used weekly mark-recapture trapping of Townsend's ground squirrels on 4 site pairs $(8$ sites total) from 11 February 1992 to 19 June 1992 during the season of squirrel activity (February-June). Each squirrel was marked with a passive integrated transponder (Schooley et al., 1993), weighed, sexed, assessed for reproductive status, and feces were collected. Trap site, trap number, and date of capture also were recorded.

Sites for parasite work were chosen to contrast both habitat type and the densities of ground squirrels in 1991. Population size was estimated using the program CAPTURE (Rexstad and Burnham, 1991). Density (animals/ha) then was estimated using an edge effect correction based on line transect theory (Burnham et al., 1980). Sites with high squirrel density (13.6 and 9.3 adults/ha) were dominated by the grass Poa segunda. Historically, these 2 sites were covered with big sage (Artemisia tridentata), but burning in the last 6- 
TABLE I. Arcsine mean $( \pm \mathrm{SD})$ and untransformed prevalences (in parentheses) of eimerian infections in adult Townsend's ground squirrels (Spermophilus townsendii) during their 1992 active season (FebruaryJune), juveniles between emergence (March) and imergence (June), and adults during juvenile activity (March-June) at the Snake River Birds of Prey Area near Boise, Idaho.

\begin{tabular}{lccc}
\hline & $\begin{array}{c}\text { Adults } \\
(\mathrm{n}=325)\end{array}$ & $\begin{array}{c}\text { Juveniles } \\
(\mathrm{n}=224)\end{array}$ & $\begin{array}{c}\text { Adults } \\
(\mathrm{n}=239)\end{array}$ \\
$\begin{array}{l}\text { Group/ } \\
\text { Eimeria } \text { spp. }\end{array}$ & February-June & $\begin{array}{c}8 \text { sites } \\
\text { March-June }\end{array}$ & $\begin{array}{c}6 \text { sites } \\
\text { March-June }\end{array}$ \\
\hline callospermophili & $39.3 \pm 4.8^{*}$ & $8.9 \pm 7.9$ & $29.7 \pm 5.3^{*}$ \\
& $(0.40)$ & $(0.11)$ & $(0.24)$ \\
adaensis & $35.6 \pm 4.5^{*}$ & $25.2 \pm 4.3$ & $36.6 \pm 5.1^{*}$ \\
& $(0.33)$ & $(0.17)$ & $(0.36)$ \\
morainensis & $16.7 \pm 7.3$ & $14.5 \pm 5.8$ & $10.0 \pm 5.9$ \\
& $(0.08)$ & $(0.06)$ & $(0.03)$ \\
bilamellata & $14.7 \pm 4.9$ & $10.1 \pm 4.6$ & $13.9 \pm 4.6$ \\
& $(0.06)$ & $(0.02)$ & $(0.05)$ \\
beecheyi & $11.6 \pm 6.1$ & $7.7 \pm 4.3$ & $12.1 \pm 5.7$ \\
& $(0.03)$ & $(0.01)$ & $(0.04)$ \\
pseudospermophili & $11.3 \pm 4.2$ & $11.0 \pm 5.5$ & $9.6 \pm 4.1$ \\
& $(0.03)$ & $(0.03)$ & $(0.02)$ \\
lateralis & $10.0 \pm 3.1$ & $7.1 \pm 3.8$ & $8.0 \pm 1.9$ \\
& $(0.02)$ & $(0.01)$ & $(0.01)$ \\
All eimerians & $51.3 \pm 7.2^{*}$ & $35.3 \pm 5.2$ & $45.3 \pm 5.7^{*}$ \\
& $(0.10)$ & $(0.33)$ & $(0.51)$ \\
\hline
\end{tabular}

* Adults in each column were compared to juveniles, but adults were not compared to each other. Significant differences $(P<0.05$, independent $t$-test) are between values in column 1 vs. column 2 or column $3 \mathrm{vs.}$ column 2 .

$8 \mathrm{yr}$ has eliminated all but a few shrubs. Sites of medium density ( 6.5 and 7.6 adults/ha) had moderate sage cover. Sites of low squirrel density ( 0.7 and 0.3 adults/ ha) were thickly vegetated with sage. Two additional low density sites ( 2.6 and 0.9 adults/ha) were predominately native winterfat (Ceratoides lanata).

As part of another study at the SRBOPA to assess the effects of parasitism on female ground squirrels, 15 fecal pellets were obtained from the first 20 adult females/trap day/site, the first 20 males for 1 trap day/ site in the beginning, middle, and end of the season ( 3 days total), and the first 10 juvenile females/trap day/ site upon emergence (late March); also, 147 fecal samples were obtained from other sites at the SRBOPA. Feces were placed in vials containing $2 \%(\mathrm{w} / \mathrm{v})$ aqueous potassium dichromate $\left(\mathrm{K}_{2} \mathrm{Cr}_{2} \mathrm{O}_{7}\right)$ and later examined for oocysts using sucrose flotation (Duszynski et al., 1982; Stout and Duszynski, 1983).

Measurements of all sporulated oocysts were made at $1,250 \times$ using both Nomarski and Neofluar oil-immersion objectives and are in micrometers with size ranges in parentheses following the means. Oocysts were measured 60-150 days after they had been collected.

An index of prevalence for eimerian infections during 1992 was calculated by summing all information from each individual into a single point, determining prevalences on each site, arcsine transforming them (modified Fisher and Tukey method [Zar, 1984]), and then averaging the values across sites. If less than 2 animals were captured on a site, that site was dropped from the analysis. Means for females were compared to means for males using an independent $t$-test (SPSS, Norusis, 1990). Because there was no significant difference between prevalence of infection in males and females, sexes are not separated in subsequent analyses. Means for juveniles were compared to means for adult captures encompassing the entire season (11 February19 June) and to means for adult captures during the period of juvenile activity (20 March-19 June) using an independent $t$-test (SPSS, Norusis, 1990). Prevalence of each eimerian species and for all 7 species combined over time was determined by pooling all captures within 10-day intervals beginning 11 February 1992. Thus, for animals captured more than once during an interval, information was summed to 1 point. Some squirrels, because they were captured frequently, contribute information to multiple intervals. The midpoint of each 10-day interval was used for all analyses. To examine significance of temporal changes, prevalences were arcsine transformed and analyzed using linear regression.

\section{DESCRIPTION}

We found 7 eimerian species in the Townsend's ground squirrels at the SRBOPA in 1992 (Table I); 5 constitute new host records and 2 are new species. We also add new structural information on $E$. morainensis that was missing from the original description.

\section{Eimeria adaensis n. sp.}

(Figs. 1-3, 10)

Oocyst usually ovoidal, wall $\sim 1.2$, composed of 2 layers: outer smooth, brownish, $\sim 3 / 4$ of total thickness; inner smooth; micropyle and oocyst residuum absent; 1-3 (usually 2 ) polar bodies $(1 \times 3)$ present, highly refractile, usually bilobed; a conspicuous shadow or membranous material present at narrow end of oocyst (Figs. 1-3); sporulated oocysts $(n=68) 19.6 \times 22.7$ $(16-22 \times 18-26)$ with length/width ratio $(\mathrm{L} / \mathrm{W}) 1.2$ (1.0-1.4); sporocysts ellipsoidal, $7.2 \times 11.9(6-10 \times$ 9-15) with $\mathrm{L} / \mathrm{W}$ ratio $1.6(1.3-2.6)$; small, almost transparent Stieda body present (Figs. 1-3), but sub- and parastieda bodies absent; sporocyst residuum a compact mass of large granules (Figs. 1,2) and occupies $\sim 1 / 4$ of sporocyst; sporozoites each with a rounded posterior refractile body (Figs. 1-3).

\section{Taxonomic summary}

Type host: Spermophilus townsendii (Bachman, 1839).

Type locality: U.S.A., Idaho, Ada County, Snake River Birds of Prey Area.

Prevalence: Varied seasonally in 1992 from $42 \%$ of the population infected in March to $<12 \%$ in June.

Site of infection: Unknown. Oocysts collected from feces.

Material deposited: Phototype (see Bandoni and Duszynski, 1988) of the sporulated oocyst in the U.S. National Museum Parasite Collection (USNMPC), Beltsville, Maryland, no. 82931. Symbiotype (see Frey et al., 1992) in the University of New Mexico Museum of Southwest Biology (UNM-MSB), MSB no. 70128 (NK25497; adult male, 192 g); collected: P. G. Wilber, 7 March 1992.

Etymology: The nomen triviale is derived from Ada, the county in Idaho in which the first infected animal was captured and-ensis (L., belonging to). 


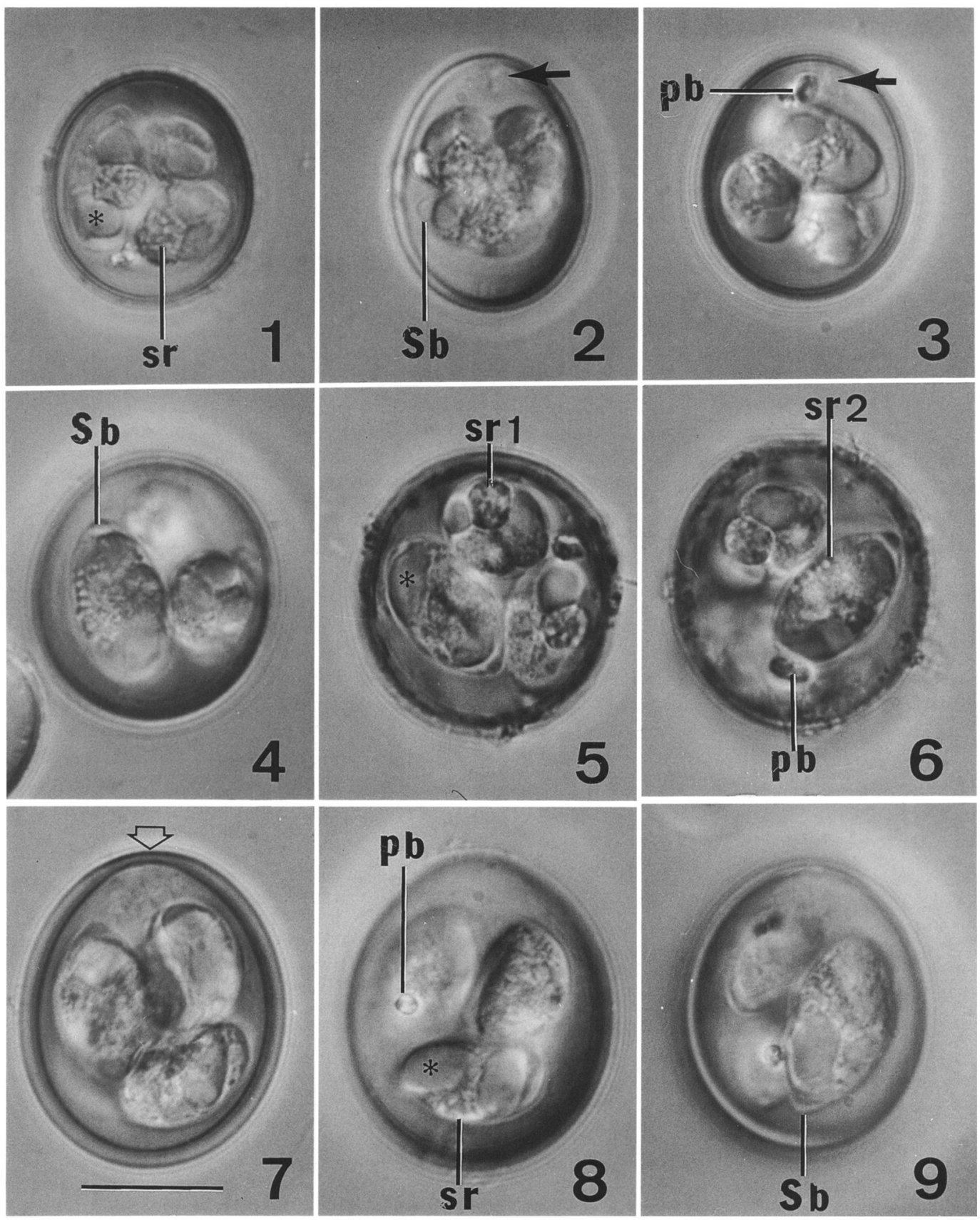

FIGURES 1-9. Photomicrographs of sporulated oocysts of various Eimeria species from Townsend's ground squirrels. 1-3. Eimeria adaensis $\mathrm{n}$. sp. Note shadow on top of oocyst in Figure 1, and membranouslike material that causes shadow (arrows) in Figures 2, 3. 4-6. Eimeria morainensis. 7-9. Eimeria pseudospermophili $\mathrm{n}$. sp. Note how oocyst wall thins at pointed end (arrow) in Figure 7. Scale bar $=10 \mu \mathrm{m}$ for all figures; pb, polar body; $\mathrm{Sb}$, Stieda body; sr, sporocyst residuum; sr1, large sporocyst residuum; sr2, small sporocyst residuum. 

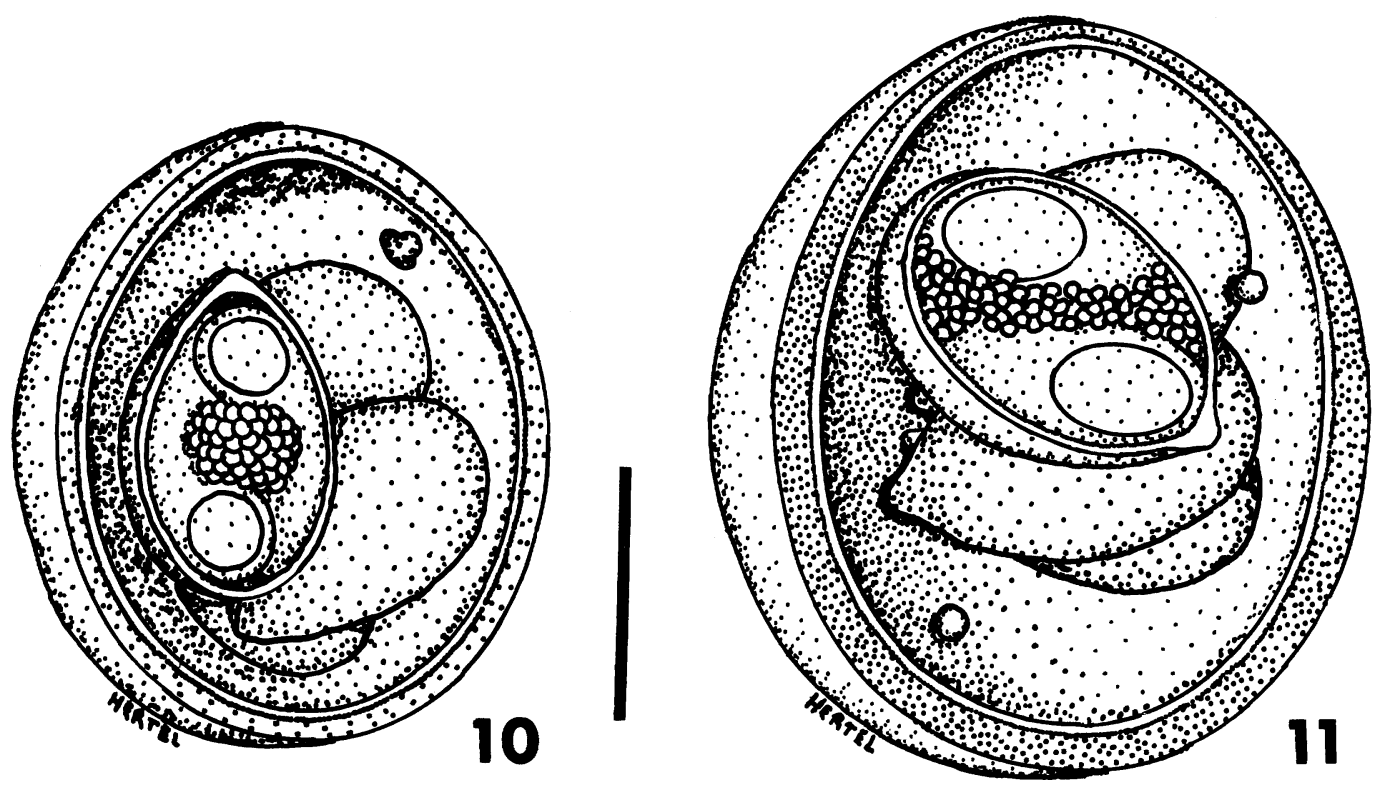

FIGURES 10, 11. Composite line drawings of sporulated oocysts of eimerians collected from feces of Spermophilus townsendii. 10. Eimeria adaensis. 11. Eimeria pseudospermophili. Scale bar $=10 \mu \mathrm{m}$.

\section{Remarks}

Sporulated oocysts of $E$. adaensis resemble those of Eimeria beecheyi Henry, 1932, from Spermophilus beecheyi in California; Eimeria beckeri Yakimoff and Sokoloff, 1935, from Spermophilus pygmaeus; Eimeria citelli Kartchner and Becker, 1930, from Spermophilus tridecimlineatus; and Eimeria franklini Hall and Knipling, 1935, from Spermophilus franklinii. They differ from those of $E$. beecheyi by being slightly larger, having a 2-layered brownish rather than a single-layered colorless oocyst wall, bilobed polar granules, and a conspicuous shadow at the narrow end of the sporulated oocyst. They differ from those of $E$. beckeri by having sporocysts with a distinct Stieda body and by the presence of polar bodies. They differ from those of $E$. citelli by being larger, having a 2-layered brownish wall rather than a 3-layered pinkish wall, possessing multiple polar bodies, lacking any oocyst residuum, and having larger sporocysts with smooth rather than nipplelike Stieda bodies. They differ from those of $E$. franklini by being slightly larger, ovoidal rather than ellipsoidal (shape index 1.2 vs. 1.4), and by lacking an oocyst residuum.

\section{Eimeria morainensis Torbett, Marquardt, and Carey, 1982 \\ (Figs. 4-6)}

Oocyst ovoidal to spherical (Figs. 4-6), wall $\sim 1.5$, composed of 2 layers: outer wall smooth, brownish, $3 / 4$ of total thickness; inner layer smooth, colorless; micropyle and oocyst residuum absent, but 1-3 highly refractile polar bodies, often bilobed (Figs. 5, 6); sporulated oocysts $(n=65) 21.0 \times 24.2(17-26 \times 20-29)$ with $\mathrm{L} / \mathrm{W}$ ratio $1.2(1.0-1.2)$; sporocysts elongate ovoidal, $7.5 \times 13.3(6-11 \times 10-16)$ with $\mathrm{L} / \mathrm{W}$ ratio 1.8 (1.4-2.1); buttonlike Stieda body present (Figs. 4-6), but sub- and parastieda bodies absent; 2 distinct sporocyst residua always present, 1 a compact spheroidal mass of tightly packed granules and occupies $1 / 4$ of sporocyst (Fig. 5); the second consists of 6-9 small globules that often lie in a line against the sporocyst wall (Figs. 4,6 ); sporozoites each with a prominent posterior refractile body that varies from round to oblong (Figs. $4,6)$.

\section{Taxonomic summary}

\section{Host: Spermophilus townsendii.}

Locality: U.S.A., Idaho, Ada County, Snake River Birds of Prey Area.

Prevalence: Varied seasonally in 1992 from $18 \%$ of the population infected in February to $<5 \%$ infected in May.

Site of infection: Unknown. Oocysts collected from feces.

Material deposited: Phototype of sporulated oocyst in the USNMPC no. 82933. Symbiotype in the UNMMSB, MSB no. 70127 (NK25473; adult female, 157 g); collected: P. G. Wilber, 14 February 1992.

\section{Remarks}

Torbett et al. (1982) first reported this species in the golden-mantled ground squirrel, Spermophilus lateralis, in northern Colorado. The oocysts that we studied were more variable in size (17-26 × 20-29 vs. $18-21$ $\times 19-26)$ and in shape (L/W 1.2 vs. 1.0$)$ than in the original description; however, the internal qualitative and quantitative features of our oocysts were consistent with those of the original description except for the presence in ours of 2 distinct sporocyst residua (see Figs. 5, 6) that Torbett et al. (1982) did not describe or include in their line drawing. The second sporocyst residuum, which we describe here, seems to be present 
in their published photomicrograph (Torbett et al., 1982: fig. 3). A more recent redescription by McAllister et al. (1991) does not appear to be $E$. morainensis because their specimen is missing the prominent nipplelike Steida body and the second sporocyst residuum. The specimen described by McAllister et al. (1991) more closely resembles $E$. adaensis.

\section{Eimeria pseudospermophili n. sp.} (Figs. 7-9, 11)

Oocyst ovoidal, wall $\sim 2.0$, except at tapered anterior end where it thins to $\sim 1.0$ (Figs. 7,9); composed of 2 layers: outer smooth, brownish, $\sim 3 / 4$ of total thickness; inner layer smooth; micropyle and oocyst residuum absent; 1-3 polar bodies present, highly refractile and generally rounded (Figs. 8, 9); sporulated oocysts $(\mathrm{n}=$ 43) $24.6 \times 28.5(21-27 \times 25-32)$ with $\mathrm{L} / \mathrm{W}$ ratio 1.2 (1.1-1.4); sporocysts elongate ovoidal (Fig. 9) $8.8 \times$ $14.2(8-10 \times 12-17)$ with $\mathrm{L} / \mathrm{W}$ ratio $1.6(1.1-2.0)$; Stieda body present (Figs. 7, 9) but sub- and parastieda bodies absent; sporocyst residuum globular, composed of coarse granules (Fig. 8) and occupies $\sim 1 / 4$ of sporocyst; sporozoites each with a large, oblong refractile body (Figs. 8, 9).

\section{Taxonomic summary}

Type host: Spermophilus townsendii.

Type locality: U.S.A., Idaho, Ada County, Snake River Birds of Prey Area.

Prevalence: Found in 1-6\% of the host population during February-June 1992.

Site of infection: Unknown. Oocysts collected from feces

Material deposited: Phototype of the sporulated oocyst in the USNMPC no. 82932. Symbiotype in the UNM-MSB, MSB no. 70126 (NK28410; juvenile female, 109 g); collected: P. G. Wilber, 12 May 1992.

Etymology: Because of its similarity in shape to Eimeria spermophili, the nomen triviale is derived from pseud (Gk., false, deceptive) and spermophili, the epithet of the eimerian it most closely resembles.

\section{Remarks}

Sporulated oocysts of E. pseudospermophili resemble Eimeria spermophili Hilton and Mahrt, 1971, but they are larger, lack an oocyst residuum, have a thicker oocyst wall, and have sporocysts that are larger (14 vs. 10) and more ellipsoidal rather than lemon-shaped (L/W $=1.6$ vs. 1.25 ).

\section{DISCUSSION}

Based on 1,184 capture events of 608 squirrels, the 3 most common eimerians (Eimeria callospermophili, Henry, 1932, Eimeria morainensis, and Eimeria adaensis) showed distinct seasonal patterns, whereas the other 4 eimerians were too rare for patterns to be discerned. Reasons for these low frequencies may be related to low levels of asexual reproduction or short patency, which make these species rare in the environment. There are no other spermophiline hosts that may serve as primary hosts for these eimerians at the SRBOPA. Of the 3 most common eimerians, the prevalence of E. callospermophili and E. morainensis decreased from February through May but increased in June (Fig. 12), whereas the prevalence of E. adaensis peaked in March but declined thereafter (Fig. 12). Prevalence of infection for all eimerians combined decreased significantly over time for all adults $(\mathrm{n}=384$, 799 captures) $\left(r^{2}=0.79, P<0.0001\right)$ but showed no trend in juveniles $(\mathrm{n}=224,385$ captures) (Fig. 13).

The reasons for midseason rather than early season peak of E. adaensis (Fig. 12) are unknown. Because the prevalence of $E$. adaensis increased as that of $E$. callospermophili and $E$. morainensis decreased, the subsequent peak in the prevalence of $E$. adaensis may be caused by competition between eimerians or by a longer prepatent period in $E$. adaensis. Because the 3 most common eimerians differ in their temporal patterns of prevalence and because animals were captured and recaptured on different dates and at different intervals, it is difficult to determine accurately both actual and expected rates of coinfection; thus, it is difficult to determine if competition is important. Stanton et al. (1992) showed that there were 3 significant positive associations in Spermophilus elegans (E. bilamellata and $E$. beecheyi; E. morainensis and E. callospermophili; E. lateralis and E. bilamellata) but no negative associations.

The decline in the prevalence of eimerians in adult squirrels during the active season (Fig. 13) might be explained by 2 hypotheses acting alone or in conjunction: The viability of oocysts decreased due to drought conditions at the SRBOPA throughout the 1992 season, or Townsend's ground squirrels acquired immunity to 1 or more species of Eimeria or both. Evidence in the literature regarding immunity to spermophiline eimerians is contradictory. Resistance to infection with $E$. callospermophili has been demonstrated in Spermophilus lateralis after 5 inoculations with 10,000 oocysts (Todd and Hammond, 1968a), but in the same study Spermophilus armatus, Spermophilus richardsoni, and Spermophilus variegatus showed no immune response. Thomas et al. (1993) could not demonstrate change in patent and prepatent periods of $E$. callospermophili in S. elegans infected twice, but they did find increased prepatent and decreased patent periods during a second infection with $E$. lateralis, Ivens and Kruidenier, 1957, in S. elegans. Todd and Hammond (1968b), however, could not demonstrate an immune response to $E$. la- 


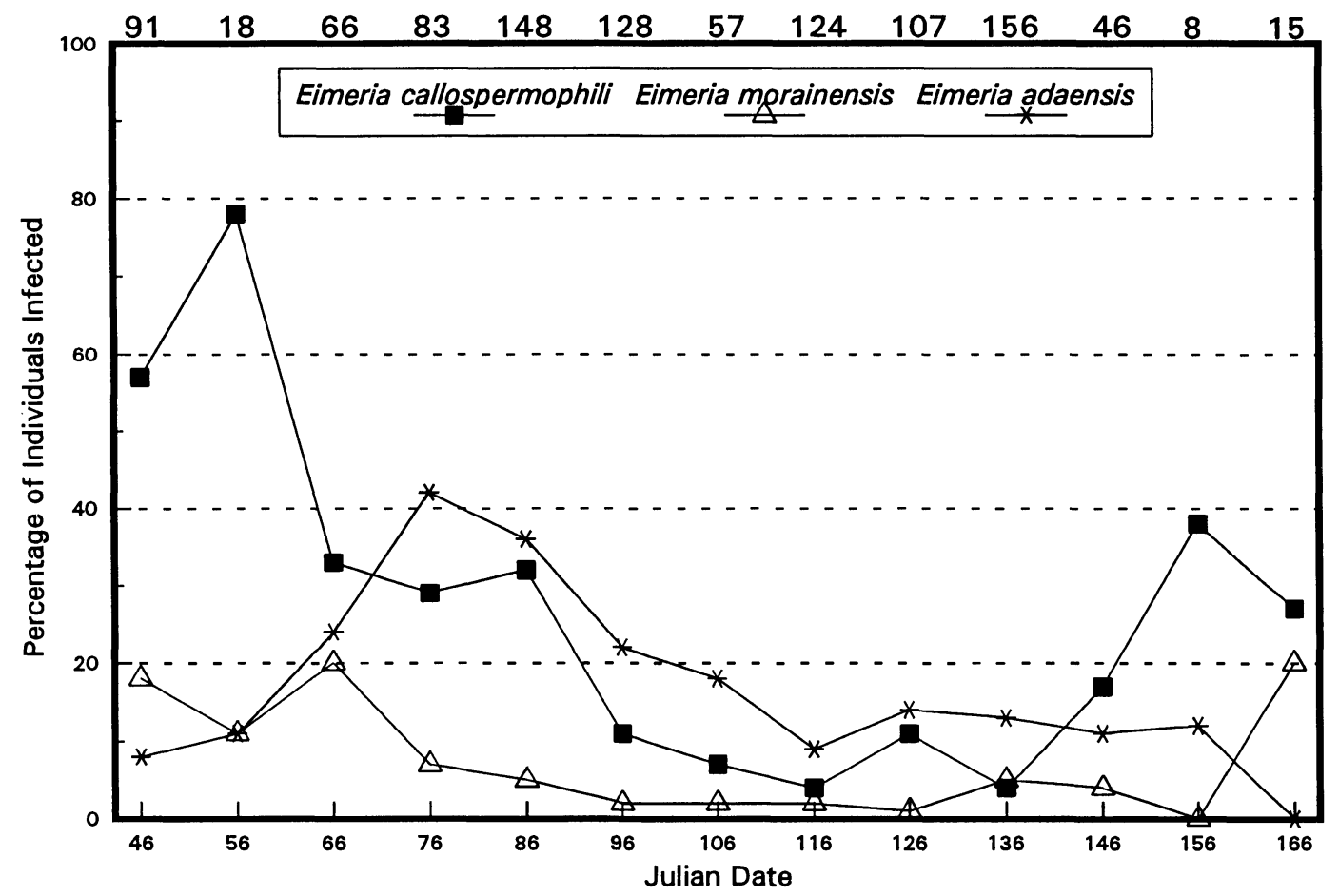

FIGURE 12. Prevalence in 1992 of the 3 most common Eimeria species by Julian date in 608 Townsend's ground squirrels (Spermophilus townsendii) captured 1,184 times. Data are combined into 10-day intervals and all multiple captures are summed, thus each point comprises unique individuals. Numbers along the top axis indicate the number of unique individuals/interval.

teralis in S. armatus, S. lateralis, or $S$. variegatus. Todd et al. (1968) demonstrated immunity to Eimeria bilamellata, Henry, 1932, in all 3 species of spermophilines examined, and Shults et al. (1990) hypothesized that immunity to $E$. $b i$ lamellata occurs in free-living S. elegans in Wyoming. Seville et al. (1992) concluded that $E$. callospermophili, E. morainensis, and E. beecheyi may be "commensals" of $S$. elegans. No repeat infection trial has been completed in the laboratory with $E$. adaensis, but we have observed individual $S$. townsendii shedding oocysts of $E$. adaensis on dates more than 30 days apart, suggesting that reinfection does occur. Because of the difficulties in determining expected and observed rates for reinfections, we cannot discern whether reinfection rates are higher or lower than would be expected by chance. In general, spermophiline immunogenic response to eimerians seems quite variable. A similar phenomenon has been reported for helminths of other rodents (Montgomery and Montgomery, 1990; Wakelin, 1992).
If immunity to eimerians in wild squirrels exists, prevalence in adult squirrels (because of greater chance of exposure) should be less in than juveniles. However, prevalence in juveniles (as measured by oocyst output) was never significantly greater than in adults (Table I). Thus, evidence supporting the hypothesis that immunity drives the temporal patterns of these eimerians is weak.

Alternatively, heat and humidity may be driving the temporal patterns of prevalence observed in this system. Eimerians apparently can survive subfreezing temperatures (Dorney, 1962; Fernando, 1982) but are susceptible to desiccation and ultraviolet radiation (Marquardt et al., 1960). Thus, severity of the winter should have little effect on eimerian survival, but drought may have a significant influence. In another study at the University of New Mexico's Long Term Ecological Research site on the Sevilleta National Wildlife Refuge near Socorro, New Mexico, we have seen that following an exceptionally dry year, prevalence of eimerians in heteromyid and cri- 


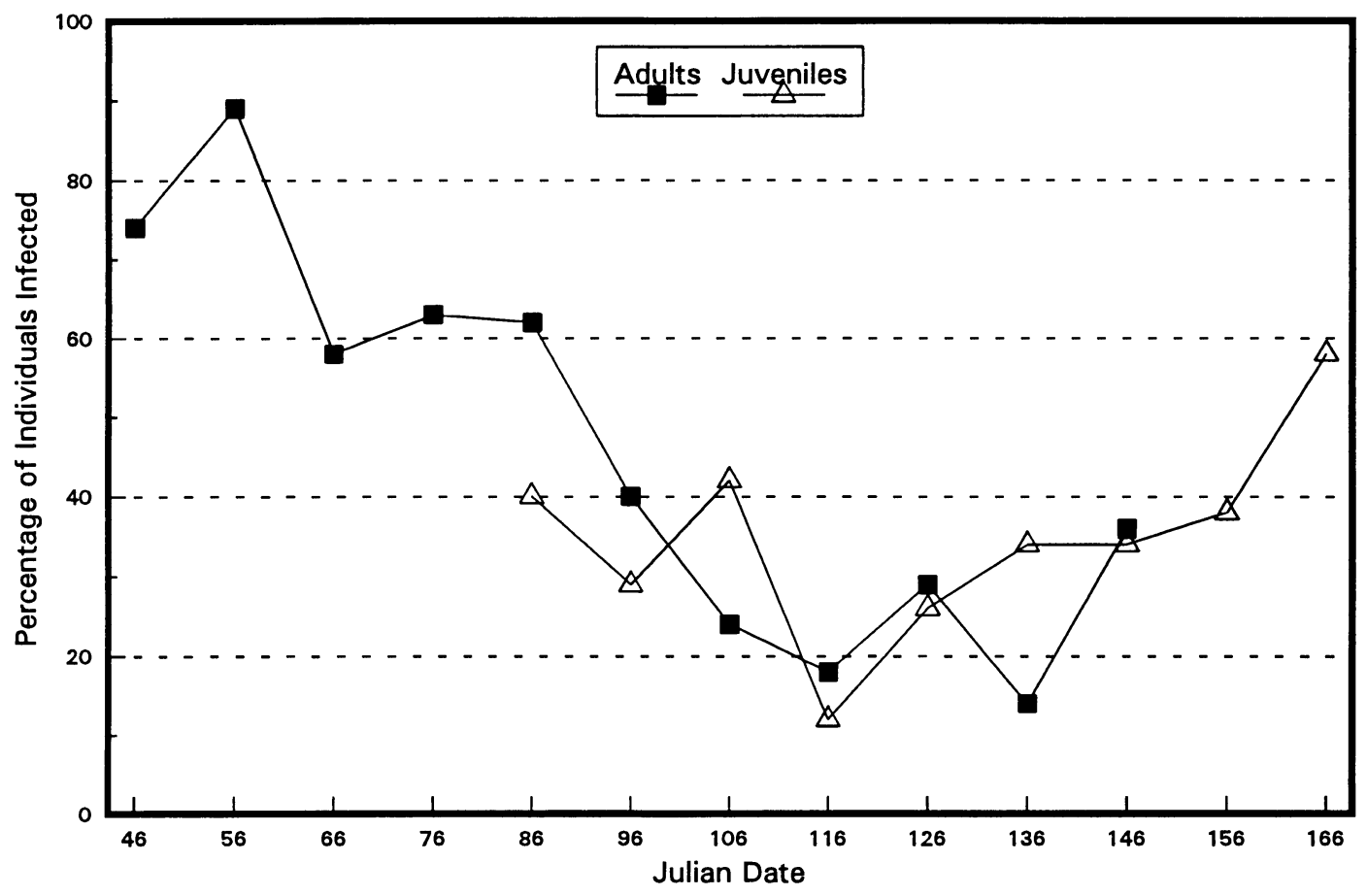

FIGURE 13. Prevalence of all Eimeria species by Julian date in juveniles ( $n=224,385$ captures) and adults ( $n=384,799$ captures). Data are combined into 10-day intervals and all multiple captures are summed; thus, each point is comprised of unique individuals.

cetid rodents decreased. During the period of squirrel activity in 1992, rainfall at the SRBOPA was minimal (National Weather Service, Boise, Idaho). Forage was all but eliminated by midApril, and more than $50 \%$ of the squirrel population died due to starvation. Townsend's ground squirrels are diurnal (Rickart, 1987) and most defecation takes place outside of the burrow. Squirrels may defecate inside the burrows (Alcorn, 1940), but a drought of this magnitude might have caused even the burrows to be dry. We found no significant relationship between squirrel density and prevalence of eimerian infection using linear regression analysis.

Our results differ from those of Shults et al. (1990), who found no consistent pattern when examining more than 1,000 S. elegans from 4 sites for $4 \mathrm{yr}$ in Wyoming and from those of Stanton et al. (1992) who stated that preliminary analysis of longitudinal data from $S$. elegans revealed no date-related trend. Spermophilus elegans shares 5 eimerians with $S$. townsendii: $E$. beecheyi, E. bilamellata, E. callospermophili, E. lateralis, and E. morainensis, but Shults et al.
(1990) removed more than 1,000 squirrels for necropsy, and subsequent changes in host-parasite interactions may have influenced their results. Alternatively, perhaps weather conditions were such that decreased viability of oocysts due to drought did not occur; thus, little change in eimerian patterns would be expected. Forrester et al. (1977) examined 182 eastern gray squirrels (Sciuris carolinensis) collected monthly over a 1 -yr period in Florida. They saw no trend in the prevalence of eimerians. Because Florida tends to be humid, desiccation of oocysts may be insignificant, and constant prevalence of eimerians may be expected.

The immune response to eimerians seems to be weak in a large number of spermophiline species, overwinter survival of oocysts in the environment probably occurs, ultraviolet radiation and heat have negative effects on oocyst viability, and eimerians are likely to overwinter in hibernating hosts (Anderson, 1971). Therefore, we propose that temporal patterns for eimerians that are largely nonimmunogenic are driven primarily by the abiotic factors of ultraviolet radiation and humidity. 


\section{ACKNOWLEDGMENTS}

We thank Dale Leatherwood and all of the technicians who collected feces from ground squirrels at the SRBOPA in 1992, Lynn Hertel for the line drawings, and Gail Olsen for the density estimates. This study was funded by $\mathrm{Bu}-$ reau of Land Management (BLM) grant as a component of the BLM/Idaho Army National Guard integrated study of raptor-prey relationships in the Snake River Birds of Prey Area (contract YA651-CTO-340032) to B.V.H., and grants from the Graduate Research Allocation Committee, the Student Research Allocations Committee, and the Vice President's Graduate Research Fund to P.G.W.

\section{LITERATURE CITED}

AlcoRn, J. R. 1940. Life history notes on the Piute Ground Squirrel. Journal of Mammalogy 21: 160170.

ANDERSON, L. C. 1971. Experimental coccidian infections in captive hibernating and non-hibernating Uinta ground squirrels, Spermophilus armatus. Ph.D. Dissertation. Utah State University, Logan, Utah, $147 \mathrm{p}$.

Ball, S. J., AND D. C. Lewis. 1984. Eimeria (Protozoa: Coccidia) in wild populations of some British rodents. Journal of Zoology 20: 373-381.

Bandoni, S., AND D. W. DuszYnSKI. 1988. A plea for improved presentation of type material for coccidia. Journal of Parasitology 74: 519-523.

Boggs, J. F., S. T. McMurry, D. M. Leslie, Jr., D. M. ENGLE, AND R. L. LOCHMILleR. 1990. Influence of habitat modification on the intestinal helminth community of cottontail rabbit populations. Journal of Wildlife Diseases, 26: 157-169.

$-,-,-1991$. Influence of habitat modification on the community of gastrointestinal helminths of cotton rats. Journal of Wildlife Diseases 27: 584-593.

Burnham, K. P., D. R. ANDerson, and J. L. LaAke. 1980. Estimation of density from line transect sampling of biological populations. Wildlife Monographs 72: 1-202.

DORNEY, R. S. 1962. Coccidiosis in Wisconsin cottontail rabbits in winter. Journal of Parasitology 48: $276-279$.

Duszynski, D. W., G. Eastham, and T. L. Yates. 1982. Eimeria from jumping mice (Zapus spp.): A new species and genetic and geographical features of Z. hudsonicus luteus. Journal of Parasitology 68: $1146-1148$.

Fernando, M. A. 1982. Pathology and pathogenicity. In The biology of the coccidia, P. L. Long (ed.). University Park Press, Baltimore, Maryland, p. 287-328.

Forrester, D. J., J. D. Shamis, G. L. Hoff, AND W. J. BIGLER. 1977. Coccidia of urban gray squirrels in northern Florida. Journal of Parasitology 63: 1045.

Frey, J. K., T. L. Yates, D. W. Duszynski, W. L. GanNon, AND S. L. Gardner. 1992. Designa- tion and curatorial management of type host specimens (symbiotypes) for new parasite species. Journal of Parasitology 78: 930-932.

Gregory, R. D., S. S. J. MONTGOMERY, AND W. I. MONTGOMERY. 1992. Population biology of $\mathrm{He}$ ligmosomoides polygyrus (Nematoda) in the wood mouse. Journal of Animal Ecology 61: 749-757.

Hudson, P. J., D. Newborn, AND A. Dobson. 1992. Regulation and stability of a free-living host-parasite system: Trichostrongylus tenuis in red grouse. I. Monitoring and parasite reduction experiments. Journal of Animal Ecology 61: 477-486.

Jenkins, E., AND A. W. GrundmanN. 1973. The parasitology of the ground squirrels of western Utah. Proceedings of the Helminthological Society of Washington 40: 76-86.

LEIBY, P. D. 1962. Helminth parasites recovered from some rodents in southeastern Idaho. American Midland Naturalist 67: 250.

Marquardt, W. C., C. M. Senger, and L. Seghetti. 1960. The effect of physical and chemical agents on the oocyst of Eimeria zurnii (Protozoa, Coccidia). Journal of Protozoology 7: 186-189.

McAllister, C. T., S. J. Upton, and B. D. Earle. 1991. Eimeria callospermophili and E. morainensis (Apicomplex: Eimeriidae) from the Mexican ground squirrel, Spermophilus mexicanus (Rodentia: Sciuridae), in south central Texas, U.S.A. Transactions of the American Microscopical Society 110: 71-74.

Minchella, D. J., AND M. E. Scott. 1991. Parasitism: A cryptic determinant of animal community structure. Trends in Ecology and Evolution 6: 250254.

Montgomery, S. S. J., AND W. I. Montgomery. 1990. Structure, stability and species interactions in helminth communities of wood mice, Apodemus sylvaticus. International Journal for Parasitology 20: 225-242.

Norusis, M. J. 1990. SPSS/PC+ statistics 4.0 for the IBM PC/XT/AT and PS/2. SPSS, Inc., USA, 313 p.

Rexstad, E., AND K. Burnham. 1991. User's guide for interactive program CAPTURE. Colorado Cooperative Fisheries and Wildlife Research Unit, Colorado State University, Ft. Collins, Colorado, $29 \mathrm{p}$.

RICKART, E. A. 1987. Spermophilus townsendii. Mammalian species 268: 1-6.

SChOOley, R. L., B. VAN HoRne, AND K. P. Burnham. 1993. Passive integrated transponders for marking free-ranging Townsend's ground squirrels. Journal of Mammalogy 74: 480-484.

Seville, R. S., H. J. Harlow, N. L. Stanton, and M. L. WAGNER. 1992. Effects of eimerian (Apicomplexa: Eimeriidae) infections on nutrient assimilation in the Wyoming ground squirrel. Journal of Parasitology 78: 881-885.

Shults, L. M., R. S. Seville, N. L. Stanton, and G. E. Menkens, Jr. 1990. Eimeria sp. (Apicomplexa: Eimeriidae) from Wyoming ground squirrels (Spermophilus elegans) and white-tailed prairie dogs (Cynomys leucurus) in Wyoming. Great Basin Naturalist 50: 327-331.

Stanton, N. L., L. M. Shults, M. Parker, and R. S. Seville. 1992. Coccidian assemblages in the 
Wyoming ground squirrel (Spermophilus elegans elegans). Journal of Parasitology 78: 323-328.

Stout, C. A., AND D. W. DuszYNSKI. 1983. Coccidia from kangaroo rats (Dipodomys spp.) in the western United States, Baja California and northern Mexico with descriptions of Eimeria merriami $\mathrm{sp.}$ $\mathrm{n}$. and Isospora sp. Journal of Parasitology 78: 406-413.

Thomas, D. M., R. S. Seville, and N. L. Stanton. 1993. Oocyst production in multispecific eimerian infections in the Wyoming ground squirrel, Spermophilus elegans elegans. Acta Parasitologica 37: 111-114.

Todd, K. S., JR., AND D. M. Hammond. 1968a. Life cycle and host specificity of Eimeria callospermophili Henry, 1932 from the Uinta ground squirrel Spermophilus armatus. Journal of Protozoology 15: $1-8$.

, AND - . 1968b. Life cycle and host specificity of Eimeria larimerensis Vetterling, 1964, from the Uinta ground squirrel Spermophilus armatus. Journal of Protozoology 15: 268-275.

,-- AND L. C. ANDERSON. 1968. Observations on the life cycle of Eimeria bilamellata Henry, 1932 in the Uinta ground squirrel Spermophilus armatus. Journal of Protozoology 15: 732-740.

Torbett, B. E., W. C. Marquardt, And A. C. Carey. 1982. A new species of Eimeria from the goldenmantled ground squirrel, Spermophilus lateralis, in northern Colorado. Journal of Protozoology 29: 157-159.

WAKELIN, D. 1992. Immunogenic and evolutionary influences on the host-parasite relationship. Developmental and Comparative Immunology 16: 345-353.

ZAR, J. H. 1984. Biostatistical analysis, 2nd ed. Prentice-Hall, Englewood Cliffs, New Jersey, 718 p. 